\title{
Up-regulation of calcitonin gene-related peptide receptors underlying elevation of skin temperature in ovariectomized rats
}

\author{
M Noguchi, Y Ikarashi, M Yuzurihara, K Mizoguchi, K Kurauchi, \\ J-T Chen ${ }^{1}$ and A Ishige \\ Kampo and Pharmacognosy Laboratories, Tsumura \& Co., 3586 Yoshiwara, Ami-machi, Inashiki-gun, Ibaraki 300-1192, Japan \\ 1J T Chen Clinic, Sunbright Twin 3F, 2-46-1 Honcho, Nakano-ku, Tokyo 164-0012, Japan \\ (Requests for offprints should be addressed to M Noguchi; Email: noguchi_masamichi@mail.tsumura.co.jp)
}

\begin{abstract}
We investigated the mechanism for the augmentation of the calcitonin gene-related peptide (CGRP)-induced elevation of skin temperature in ovariectomized (OVX) rats. I.v. injection of $\alpha$ CGRP $(10 \mu \mathrm{g} / \mathrm{kg})$ elevated skin temperature of the hind paws. The elevation was significantly greater in OVX rats than in sham-operated rats and was inhibited by pretreatment with human $\mathrm{CGRP}_{8-37}$ $(100-1000 \mu \mathrm{g} / \mathrm{kg}$ i.v.), a CGRP receptor antagonist, in a dose-dependent manner. In addition, ovariectomy not only potentiated vasorelaxation due to $\alpha$ CGRP but increased the number of CGRP receptors in mesenteric arteries. Further, the plasma concentration of endogenous
\end{abstract}

CGRP was significantly lower in OVX rats. These results suggest that the low concentration of plasma CGRP due to ovarian hormone deficiency may induce the increase in the number of CGRP receptors due to up-regulation. Therefore, the increased number of CGRP receptors may be responsible for potentiation of exogenous $\alpha$ CGRPinduced elevation of skin temperature in OVX rats. The mechanism underlying the hot flashes observed in menopausal women may also involve, in part, the up-regulation of CGRP receptors following ovarian hormone deficiency. Journal of Endocrinology (2002) 175, 177-183

\section{Introduction}

Calcitonin gene-related peptide (CGRP) is a 37 amino acid regulatory neuropeptide derived from alternative splicing of the calcitonin/CGRP gene (Rosenfeld et al. 1983). It exists in the central nervous system and peripheral nerves of the vascular wall (Lee et al. 1985, Wanaka et al. 1987). In humans (Gennari \& Fischer 1985, McEwan et al. 1988) and rats (Kobayashi et al. 1995, Shen et al. 2001), administration of CGRP not only decreased arterial blood pressure and resistance of the peripheral vascular bed but also elevated skin temperature by increasing blood flow. These studies have shown CGRP to be a potent vasodilator that plays an important role in hemodynamic changes related to regulation of skin temperature.

A hot flash, which often occurs in menopausal women, generally begins with a sudden outpouring of sweat and an increase in heart rate and peripheral blood flow, causing a drastic increase in skin temperature as blood flows to the skin (Kronenberg 1994, Kobayashi et al. 1995). Chen et al. (1993) clinically demonstrated a positive correlation between plasma CGRP levels and the frequency of hot flashes in menopausal women and also an increase in plasma CGRP levels during hot flashes in the same patient. Kobayashi et al. (1995) reported that CGRP- induced elevation of skin temperature was significantly greater in ovariectomized (OVX) rats. These suggest that CGRP plays an important role in the occurrence of hot flashes due to ovarian hormone deficiency in women during the menopause. However, the mechanism underlying hot flashes has not been clarified. In the present study, therefore, we investigated the mechanism for elevation of skin temperature induced by CGRP in OVX rats.

\section{Materials and Methods}

\section{Animals}

Ten-week-old female Sprague-Dawley rats weighing 200-250 g were purchased from Charles River Laboratories (Yokohama, Japan). The animals were allowed free access to water and standard laboratory food and housed in stainless steel cages at a temperature of $23 \pm 2{ }^{\circ} \mathrm{C}$, relative humidity of $55 \pm 10 \%$ and a $12 \mathrm{~h}$ light:12 h darkness cycle, with lights on from 0700 to 1900 h daily.

The rats were anesthetized with sodium pentobarbital (50 mg/kg i.p.) and bilaterally ovariectomized or shamoperated as controls. These animals were used 3 weeks 
after the surgery. A surgical technique for ovariectomy that has been established by monitoring decreased estradiol levels in plasma and decreased tissue weight of the uterus was used in the present study.

All experimental procedures were performed according to the Guidelines for the Care and Use of Laboratory Animals approved by the Laboratory Animal Committee of Tsumura \& Co.

\section{Reagents}

Rat $\alpha$ CGRP and human $\mathrm{CGRP}_{8-37}$ were purchased from Peptide Institute Inc. (Osaka, Japan). ${ }^{125}$ I-CGRP (specific activity $2000 \mathrm{Ci} / \mathrm{mmol}$ ) was purchased from Peninsula Laboratories Inc. (San Carlos, CA, USA). Prostaglandin (PG) $\mathrm{F}_{2 \alpha}$, urethane, $\alpha$-chloralose and bacitracin were purchased from Sigma Chemical (St Louis, MO, USA). Aprotinin was purchased from Wako Pure Chemical Industries Ltd (Osaka, Japan). Sodium pentobarbital was purchased from Dinabot Laboratories (North Chicago, IL, USA). Other reagents used for analysis were the highest purity commercially available.

\section{Measurement of skin temperature}

OVX $(n=33)$ or sham-operated $(n=34)$ rats were anesthetized with i.p. co-injection of urethane $(0.75 \mathrm{~g} / \mathrm{kg})$ and $\alpha$-chloralose $(0.06 \mathrm{~g} / \mathrm{kg})$, and then two thermistor probes (SXN-54; Technol Seven Co. Ltd, Yokohama, Japan) were taped to the plantar face of both hind feet to measure the skin temperature. Forty minutes later, the mean temperature was automatically measured at $5 \mathrm{~min}$ intervals throughout the experiment. Data were recorded by a K932 recording device (Technol Seven Co. Ltd). Human CGRP ${ }_{8-37}(100,500$ or $1000 \mu \mathrm{g} / \mathrm{kg})$ dissolved in saline was injected i.v. into the tail vein after basal temperature was stable, and $\alpha$ CGRP $(10 \mu \mathrm{g} / \mathrm{kg}$ i.v. $)$ dissolved in saline was injected 10 min later.

The area under the temperature curve (AUC) following the injection of $\alpha$ CGRP was calculated using PAG-CP (Pharmacokinetic Analysis and Graphics for Clinical Pharmacology) analysis (Medical Research AS Medica, Osaka, Japan).

\section{Measurement of vasorelaxation response in isolated rat mesenteric vascular beds}

Changes in the resistance of the peripheral vascular bed were evaluated according to the method described by Kawasaki et al. (1988). In brief, a section of mesenteric vascular bed that included small resistance arteries was isolated from OVX $(n=11)$ or sham-operated $(n=9)$ rats anesthetized with pentobarbital $(50 \mathrm{mg} / \mathrm{kg}$ i.p.). The isolated vascular bed was placed in a water-jacketed organ bath maintained at $37^{\circ} \mathrm{C}$ and perfused at a constant rate of $5 \mathrm{ml} / \mathrm{min}$ using a peristaltic pump (AC-2110; Atto Co.,
Tokyo, Japan) with a modified Krebs solution gassed with $5 \% \mathrm{CO}_{2}$ in $\mathrm{O}_{2}$. The modified Krebs solution was composed of (in $\mathrm{mM}$ ): $\mathrm{NaCl} 120 \cdot 0, \mathrm{KCl} 5 \cdot 0, \mathrm{MgSO}_{4} 1 \cdot 2$, $\mathrm{NaHCO}_{3} 25 \cdot 0, \mathrm{CaCl}_{2} 2 \cdot 4$ and glucose 5.0. Changes in the perfusion pressure were measured with a pressure transducer (San-ei Co. Ltd, Tokyo, Japan) and recorded on a polygraph (Rika Denki Co. Ltd, Tokyo, Japan). After the basal pressure was stable, $10 \mu \mathrm{M} \mathrm{PGF}_{2 \alpha}$ was continuously perfused to elevate the pressure by vasocontraction of the vascular bed. After the $\mathrm{PGF}_{2 \alpha}$-induced vasocontraction reached a plateau, various concentrations of $\alpha$ CGRP $\left(10^{-11}-10^{-9} \mathrm{~mol} / 10 \cdot 0 \mu \mathrm{l}\right)$ were added to the perfusate to evaluate the vasorelaxation. The relaxation rate was expressed as a percentage of the maximum pressure obtained by the $\mathrm{PGF}_{2 \alpha}$-induced contraction.

\section{CGRP receptor binding assay}

Plasma membrane from rat mesenteric arteries was prepared according to the method described by Wei et al. (1976). Mesenteric vascular beds isolated from decapitated OVX $(n=20)$ or sham-operated $(n=20)$ rats were placed in cold $0.25 \mathrm{M}$ sucrose. The mesenteric arteries obtained by removing fatty tissue, lymph nodes and veins from the vascular beds were homogenized in $0.25 \mathrm{M}$ sucrose with a Polytron homogenizer (Kinematica Inc., Cincinnati, OH, USA) at setting 7 for $30 \mathrm{~s}$. The crude membrane fraction (pellet) was obtained by centrifugation at $100000 \mathrm{~g}$ at $4{ }^{\circ} \mathrm{C}$ for $30 \mathrm{~min}$. The fraction was resuspended in $5.0 \mathrm{ml}$ $0 \cdot 25 \mathrm{M}$ sucrose and layered on $5.0 \mathrm{ml} 29 \%$ sucrose solution. After centrifugation at $100000 \mathrm{~g}$ for $120 \mathrm{~min}$, the plasma membrane fraction (the middle layer) was collected. The membrane fraction was washed with $0 \cdot 25 \mathrm{M}$ sucrose and centrifuged at $100000 \boldsymbol{g}$ for $30 \mathrm{~min}$. The sediment was resuspended in $50 \mathrm{mM}$ Tris- $\mathrm{HCl}$ buffer, $\mathrm{pH}$ $7 \cdot 4$, containing $5 \mathrm{mM} \mathrm{MgCl}$ and $0 \cdot 25 \mathrm{M}$ sucrose. The concentration of membrane protein was determined by the method of Lowry et al. (1951). Finally, the concentration of the membrane suspension was adjusted to $1.0 \mathrm{mg} / \mathrm{ml}$ with the buffer.

CGRP receptor binding assay was performed by a modification of the method of Wimalawansa et al. (1987). In brief, the membrane suspension (20-25 $\mu$ g protein) was incubated with various concentrations of ${ }^{125}$ I-CGRP in $100 \mu \mathrm{l} 50 \mathrm{mM}$ Tris-HCl buffer, $\mathrm{pH} 7 \cdot 4$, containing $5 \mathrm{mM}$ $\mathrm{MgCl}_{2}, 2 \mathrm{mM}$ EGTA, $1.0 \%$ BSA, $2 \mathrm{mM}$ bacitracin, $200 \mathrm{kIU} / \mathrm{ml}$ aprotinin, $50 \mathrm{mM} \mathrm{NaCl}$ and $0 \cdot 25 \mathrm{M}$ sucrose. After incubation at $23^{\circ} \mathrm{C}$ for $1 \mathrm{~h}$, the incubation medium was passed through a GF/B filter (Whatman International Ltd, Maidstone, Kent, UK) that had been pre-soaked in polyethylenamine for $1 \mathrm{~h}$. Receptor-ligand complexes on the filter were rinsed three times with $3 \mathrm{ml}$ ice-cold $50 \mathrm{mM}$ Tris- $\mathrm{HCl}$ buffer, $\mathrm{pH} 7 \cdot 4$, containing $5 \mathrm{mM}$ $\mathrm{MgCl}_{2}$ and $0 \cdot 25 \mathrm{M}$ sucrose. Radioactivity on the filter was counted by a COBRA II autogamma counting system (Packard, Meriden, CT, USA). Non-specific binding was 
determined by adding $0.5 \mu \mathrm{M}$ unlabeled CGRP instead of the labeled peptide. The maximal number of binding sites $\left(\mathrm{B}_{\text {max }}\right)$ and the dissociation constant $\left(K_{\mathrm{d}}\right)$ were calculated by Scatchard analysis.

\section{RIA of plasma CGRP}

The blood (approximately $6 \mathrm{ml}$ ) from decapitated OVX $(n=6)$ or sham-operated $(n=5)$ rats was collected in polypropylene tubes containing $6.0 \mathrm{mg}$ EDTA and $3000 \mathrm{kIU}$ aprotinin and centrifuged at $1500 \mathrm{~g}$ at $4{ }^{\circ} \mathrm{C}$ for 15 min. Plasma $(2 \mathrm{ml})$ was acidified with $160 \mu \mathrm{l}$ of a mixture consisting of $5.0 \%$ formic acid, $1.0 \%$ trifluoroacetic acid (TFA), 80\% $1 \mathrm{M} \mathrm{HCl}$ and $1.0 \% \mathrm{NaCl}$. The acidified plasma was centrifuged at $7000 \mathrm{~g}$ at $4{ }^{\circ} \mathrm{C}$ for $20 \mathrm{~min}$. The supernatant was put into an activated C-18 Sep-Pak disposable cartridge column (Amersham Pharmacia Biotech, Little Chalfont, Bucks, UK) and eluted with a mixture $(2 \mathrm{ml})$ of methanol/water/TFA (90:9:1). The eluate was vacuum-dried and stored at $-80{ }^{\circ} \mathrm{C}$ until assay. On the day of the assay, the frozen sample was thawed in a small amount $(<20 \mu \mathrm{l})$ of $0 \cdot 1 \%$ TFA at $4{ }^{\circ} \mathrm{C}$ over a $30 \mathrm{~min}$ period. The CGRP level in each sample was measured in duplicate using a rat CGRP RIA Kit (Peninsula Laboratories Inc., San Carlos, CA, USA).

\section{Statistical analysis}

All values were represented as means \pm S.E.M. The statistical significance of skin temperature or vasorelaxation data was evaluated by a two-way or one-way ANOVA followed by Dunnett's $t$-test. Student's $t$-test was used for comparison of plasma CGRP levels in OVX and shamoperated rats. For all tests the significance level was accepted at $P<0 \cdot 05$.

\section{Results}

aCGRP-induced elevation of skin temperature and antagonism with the CGRP receptor antagonist human CGRP $_{8-37}$ in OVX rats

Changes in skin temperature following injection of $\alpha$ CGRP $(10 \mu \mathrm{g} / \mathrm{kg}$ i.v.) in sham-operated or OVX rats are shown in Fig. 1. The skin temperature was maximally elevated 40-50 min after the injection of $\alpha$ CGRP in both operated rats, and thereafter it recovered basal levels by 120 min. The AUC data shown in Fig. 1C indicated that the elevation of skin temperature in the control group $(P<0 \cdot 01)$ and $\mathrm{CGRP}_{8-38}(500 \mu \mathrm{g} / \mathrm{kg}$ i.p. $)$-treated group $(P<0 \cdot 05)$ was significantly greater in OVX rats than in sham-operated rats. The CGRP-induced elevations of skin temperature in both operated rats were inhibited by pretreatment with human $\mathrm{CGRP}_{8-37}(100-1000 \mu \mathrm{g} / \mathrm{kg}$ i.p.) in a dose-dependent manner.

Vasorelaxation effect of aCGRP on $P_{2} F_{2 a}$-induced contraction of mesenteric vascular beds isolated from OVX rats

Changes in the resistance of the peripheral vascular bed as an index of vasocontraction or vasorelaxation were examined in OVX and sham-operated rats. Continuous perfusion of $\mathrm{PGF}_{2 \alpha}(10 \mu \mathrm{M})$ contracted the isolated mesenteric vascular beds, and the contraction reached a plateau. No significant differences were observed in the degree of $\mathrm{PGF}_{2 \alpha}$-induced contraction between vascular beds obtained from OVX $(40 \cdot 27 \pm 0.71 \mathrm{mmHg})$ and sham-operated rats $(41.57 \pm 1.42 \mathrm{mmHg})$. As shown in Fig. 2, aCGRP $\left(10^{-11}-10^{-9} \mathrm{~mol}\right)$ relaxed the $\mathrm{PGF}_{2 \alpha^{-}}$ induced contraction in the vascular bed isolated from OVX or sham-operated rats in a dose-dependent manner. The vasorelaxation effect, however, was significantly greater in OVX rats than in sham-operated rats $(F(1,108)=29 \cdot 812, P<0 \cdot 001)$.

Changes in ${ }^{125}$ I-CGRP binding in isolated mesenteric arteries of OVX rats

The effect of ovariectomy on ${ }^{125}$ I-CGRP binding was investigated in isolated mesenteric arteries. The Scatchard plot is shown in Fig. 3. The correlation between the bound/free ratio and specific ${ }^{125}$ I-CGRP binding was linear with a $K_{\mathrm{d}}$ of $0.333 \mathrm{nM}$ and a $\mathrm{B}_{\max }$ of $5.76 \mathrm{fmol} / \mathrm{mg}$ protein in sham-operated rats or with a $K_{\mathrm{d}}$ of $0.387 \mathrm{nM}$ and a $B_{\max }$ of $20 \cdot 18 \mathrm{fmol} / \mathrm{mg}$ protein in OVX rats; the $\mathrm{B}_{\max }$ value was approximately 3.5 times higher in OVX rats than in sham-operated rats, although no differences were observed in the $K_{\mathrm{d}}$ values between the two groups.

\section{Changes in plasma concentration of endogenous CGRP in OVX rats}

The effect of ovariectomy on plasma concentration of endogenous CGRP was examined 3 weeks after ovariectomy or sham operation. The CGRP level in OVX rats $(7 \cdot 14 \pm 0.53 \mathrm{pmol} / \mathrm{l})$ was significantly lower $(P<0 \cdot 01)$ than that in sham-operated rats $(13.46 \pm 1.56 \mathrm{pmol} / \mathrm{l})$.

\section{Discussion}

We first of all demonstrated in the present study that i.v. injection of $\alpha$ CGRP caused an elevation of skin temperature that was significantly greater in OVX rats than in sham-operated rats. This agrees with the results of a previous study reported by Kobayashi et al. (1995). In addition, we demonstrated that the $\alpha$ CGRP-induced elevation of skin temperature was inhibited by human CGRP $_{8-37}$ in both OVX and sham-operated rats. Human 
CGRP $_{8-37}$ is the most potent CGRP antagonist available to date and appears to differentiate between the two CGRP receptors called $\mathrm{CGRP}_{1}$ and $\mathrm{CGRP}_{2}$. CGRP

(A)

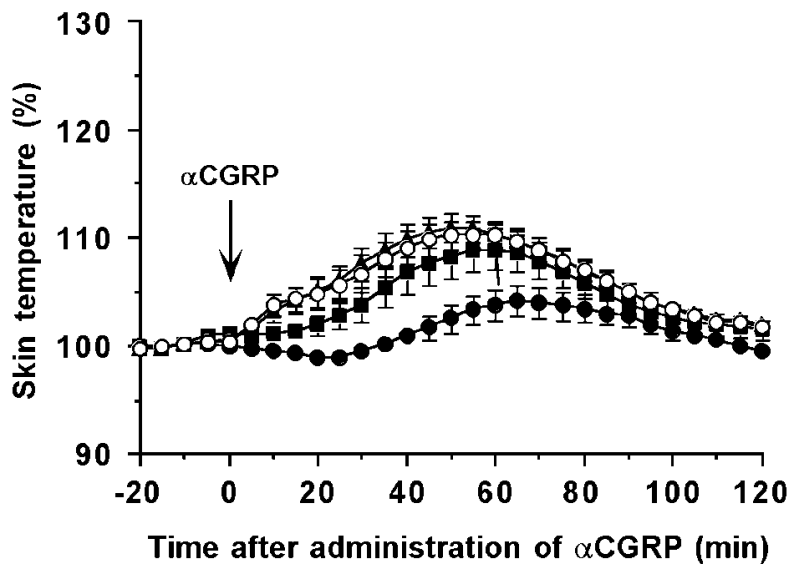

(B)

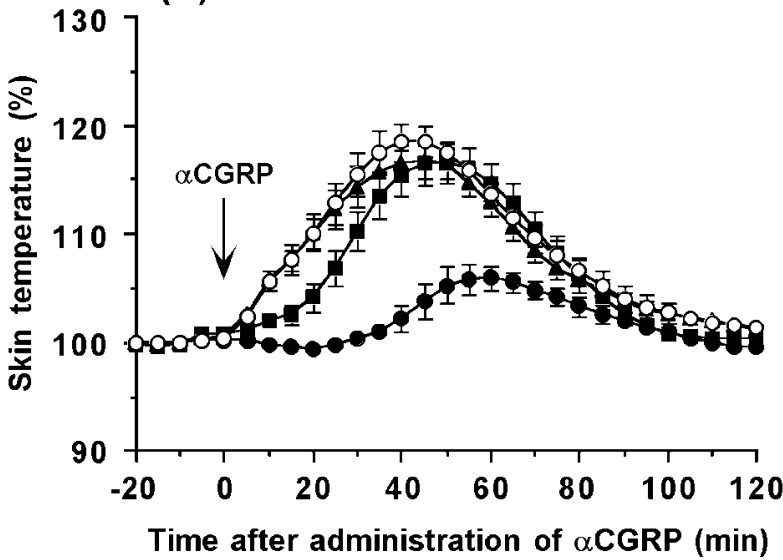

(C)

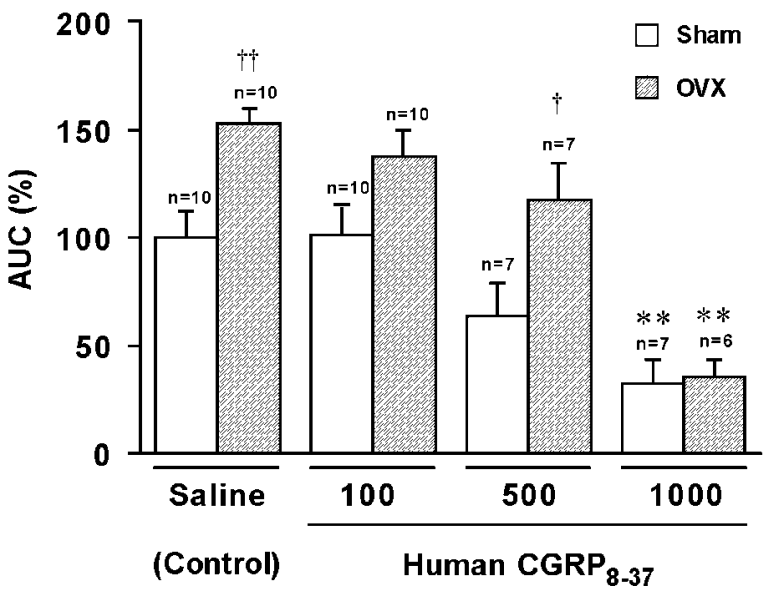

receptors are characterized by their sensitivity to the antagonistic actions of $\mathrm{CGRP}_{8-37}$, whereas $\mathrm{CGRP}_{2}$ receptors are resistant to $\mathrm{CGRP}_{8-37}$ (Dennis et al. 1990, Mimeault et al. 1991, Holzer 1992). It has been demonstrated that $\mathrm{CGRP}_{1}$ receptor antagonist human $\mathrm{CGRP}_{8-37}$ exhibits higher affinity for the CGRP receptors in rat left atrium, when human $\alpha \mathrm{CGRP}$ and rat $\alpha \mathrm{CGRP}$ are used as an agonist; human $\mathrm{CGRP}_{8-37}$ blocks human $\alpha \mathrm{CGRP}-$ and rat $\alpha$ CGRP-induced responses with $\mathrm{pA}_{2}$ values of $7 \cdot 17$ and $7 \cdot 35$ respectively (Juaneda et al. 2000, Wu et al. 2000). In addition, human $\mathrm{CGRP}_{8-37}$ inhibits rat aCGRP-induced vasorelaxation in isolated rat mesenteric vascular beds (Han et al. 1990). These suggest that human $\mathrm{CGRP}_{8-37}$ is an effective antagonist against rat and human $\mathrm{CGRP}_{1}$ receptors. Therefore, it is suggested that the $\alpha C G R P-i n d u c e d$ elevation of skin temperature in the present study may be due to the response through CGRP $_{1}$ receptors.

The mesenteric vascular bed is densely innervated by CGRP-containing sensory nerves (Uddman et al. 1986, Ishida-Yamamoto \& Tohyama 1989), and in vitro electrical field stimulation indicated that activation of these nerves induces vasodilation (Kawasaki et al. 1988, Fujimori et al. 1989, 1990). Lei et al. (1994) suggested that the main CGRP receptor type mediating relaxation in rat mesenteric small arteries is the $\mathrm{CGRP}_{1}$ subtype. The ${ }^{125}$ I-CGRP binding assay in the present study indicated that the specific binding was linear in the arteries isolated from OVX and sham-operated rats and that no significant difference in the $K_{\mathrm{d}}$ values was observed between the differently treated rats, suggesting a single class of highaffinity specific binding sites for CGRP in the mesenteric arteries. These suggest that mesenteric vascular beds including small arteries are useful materials to examine the changes in $\mathrm{CGRP}_{1}$ receptor and CGRP-mediated responses, in place of skin arteries. To clarify the mechanism underlying the potentiation of $\alpha \mathrm{CGRP}\left(\mathrm{CGRP}_{1}\right.$

Figure 1 Effects of the CGRP antagonist human $\mathrm{CGRP}_{8-37}$ on the skin temperature response to $\alpha C G R P$ in sham-operated $(A)$ and OVX rats (B). AUC data following injection of $\alpha$ CGRP $(10 \mu \mathrm{g} / \mathrm{kg}$ i.v.) in each treatment are shown in (C). $\alpha$ CGRP was administered 10 min after pretreatment with saline $(O)$ or human $\mathrm{CGRP}_{8-37}$

$(100(\boldsymbol{\Delta}), 500(\mathbf{\square})$ or $1000(\mathbf{O}) \mu \mathrm{g} / \mathrm{kg}$ i.v.). The number of animals in each group $(n=6-10)$ is indicated in $(\mathrm{C})$. Each value is expressed as the mean \pm S.E.M. The AUC in each treatment group is expressed as a percentage of AUC in the sham-operated control group. In the AUC data, statistical significance of skin temperature in sham-operated or OVX rats was analysed by a one-way or two-way ANOVA followed by Dunnett's test. Factorial two-way ANOVA analysis revealed that there were significant effects of group $(F(1,59)=15 \cdot 693, P<0 \cdot 001)$ and $C_{G R P}{ }_{8-37}$ dose $(F(3,59)=19 \cdot 259, P<0 \cdot 001)$. In this Figure, significance with post hoc analyses (Dunnett's t-test) following the ANOVA analyses are indicated; ${ }^{* *} P<0.01$ compared with the corresponding control. The effect of ovariectomy on $\alpha$ CGRP-induced elevation of skin temperature was compared between sham-operated control and OVX control using Student's $t$-test; $\uparrow P<0 \cdot 05, \dagger+P<0 \cdot 01$. 


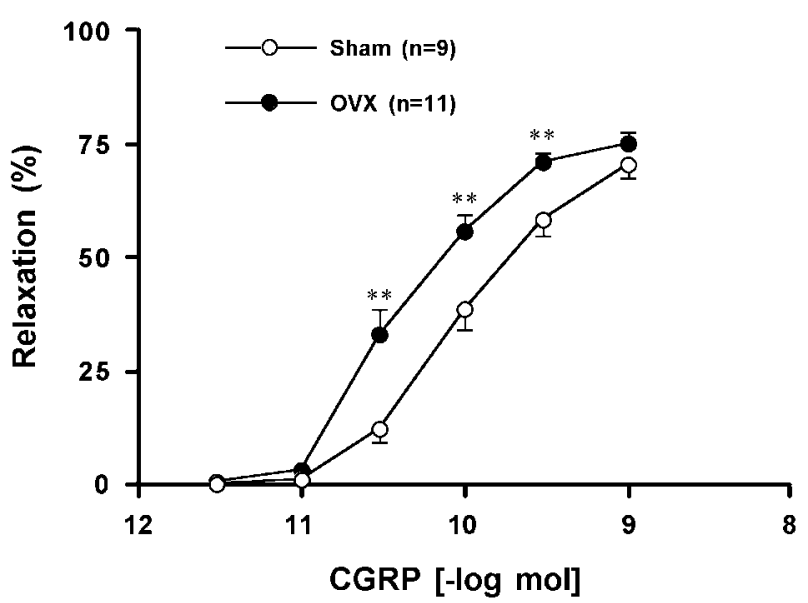

Figure 2 Vasodilator response of $\alpha$ CGRP on $\mathrm{PGF}_{2 \alpha}$-induced contraction of mesenteric vascular beds isolated from sham-operated and OVX rats. Data calculated as percent relaxation of the maximum pressure obtained by $\mathrm{PGF}_{2 \alpha}$-induced contraction are expressed as means \pm S.E.M. Factorial two-way ANOVA analysis revealed that there were significant effects of group $(F(1,108)=29 \cdot 812, P<0 \cdot 001)$, $\alpha$ CGRP dose $(F(5,108)=210 \cdot 201, P<0 \cdot 001)$ and interaction of group $\times$ dose $(F(5,108)=3 \cdot 836, P<0 \cdot 01)$. In this Figure, significance with post hoc analyses (Dunnett's $t$-test) following the ANOVA analysis are indicated; ${ }^{* *} P<0 \cdot 01$ compared with corresponding values in sham-operated rats.

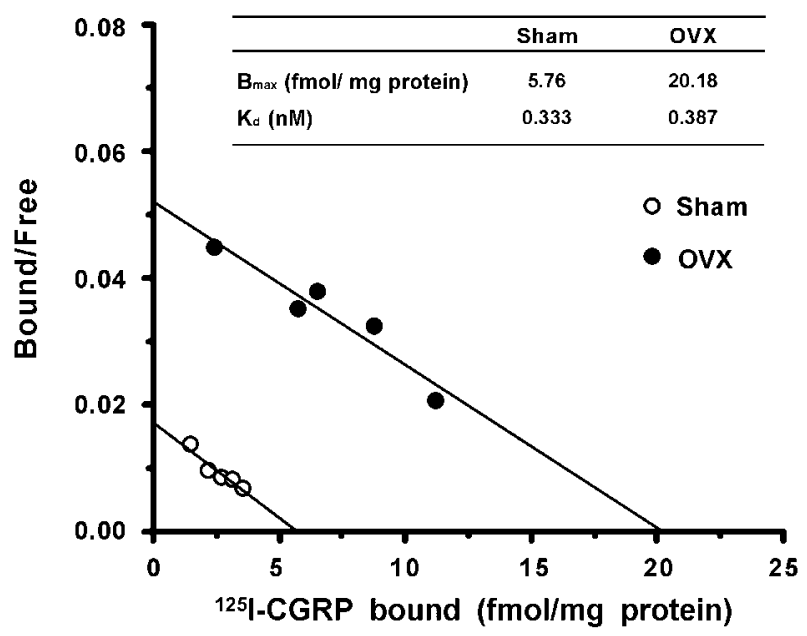

Figure 3 Scatchard plot of CGRP receptor binding assay in mesenteric arteries isolated from sham-operated and OVX rats. Each value is the mean of duplicate determinations using the pooled plasma membrane isolated from sham-operated $(n=20)$ or OVX $(n=20)$ rats.

activator)-induced elevation of skin temperature in OVX rats, therefore, we investigated the changes in aCGRPinduced relaxation and the number of CGRP receptors using mesenteric arteries isolated from OVX rats. We demonstrated that infusion of $\alpha$ CGRP induced vasodilation (or vasorelaxation) of isolated arteries contracted by $\mathrm{PGF}_{2 \alpha}$. It has been demonstrated that CGRP is a potent vasodilator and causes a regional blood flow increase in rats (Marshall et al. 1986, Kawasaki et al. 1988, Han et al. 1990, Kobayashi et al. 1995), and that skin temperature in rats is regulated by regional blood flow (Rand et al. 1965). Therefore, the elevation of skin temperature induced by $\alpha$ CGRP in the present study is thought to be mediated by the blood flow increase following the vasodilator action of this peptide in the skin. This finding in rats is consistent with the previous observation that CGRP increases regional blood flow in humans, especially in the skin (Jager et al. 1990, Jernbeck et al. 1990). We also demonstrated that $\alpha$ CGRP-induced vasorelaxation was significantly greater in OVX rats than in sham-operated rats, suggesting that ovarian hormone deficiency following OVX causes the skin temperature increase through the hypervasodilation. The hypervasodilation is thought to be due to the increase in the number of CGRP receptors in arteries because the $\mathrm{B}_{\max }$ value indicating the number of CGRP receptors was higher in OVX rats.

Endogenous CGRP synthesized primarily in dorsal root ganglia neurons is transported towards the perivascular nerve endings and released into the circulation (Zaidi et al. 1985, Holzer 1992). In the present study, the endogenous CGRP level in the circulation was significantly lower in OVX rats than in sham-operated rats, suggesting that ovarian hormone deficiency following ovariectomy decreases the plasma CGRP level. It has been reported that both estrogen and progesterone, which are ovarian hormones, stimulate CGRP peptide synthesis in dorsal root ganglia neurons through increasing CGRP mRNA (Gangula et al. 2000a). Plasma CGRP levels in rats and humans have been reported to increase with pregnancy and decrease postpartum (Stevenson et al. 1986, Saggese et al. 1990, Gangula et al. 2000b). These findings suggest that ovarian hormones may be responsible for increased CGRP levels in the circulation. Therefore, it is considered that the decrease in plasma CGRP level in OVX rats is due to ovarian hormone deficiency following ovariectomy. Taken together, the present study suggests that the decrease of circulatory endogenous CGRP following ovarian hormone deficiency may induce up-regulation of CGRP receptors, i.e. the increase in number of the receptors.

Other vasoactive peptides such as substance $\mathrm{P}$ and vasoactive intestinal peptide have been shown to induce vasodilation in mesenteric arteries, as well as CGRP (Kawasaki et al. 1988, Ishida-Yamamoto \& Tohyama 1989). The CGRP family, such as adrenomedullin and amylin that have structural similarity to CGRP, is also widely distributed in various peripheral tissues as well as in the central nervous system, and induces a broad variety of biogenic effects including the most potent vasodilatory action (Juaneda et al. 2000). However, effects of these vasoactive neuropeptides on skin temperature have been little investigated. Therefore, we do not rule out the possibility that these neuropeptides induce potentiation of 
the increase in skin temperature in OVX. They should be considered in future studies.

In conclusion, $\alpha$ CGRP-induced elevation of skin temperature was potentiated in OVX rats. This result was accompanied by parallel increases in blood flow caused by vasodilation and up-regulation of CGRP receptors following the lower concentration of plasma CGRP in OVX rats. On the basis of these results, we speculate that ovarian hormone deficiency increases CGRP receptors and consequently amplifies the stimulatory effects of CGRP to elevate skin temperature. A majority of hot flashes are reported by women around menopause, and are a consequence of decreasing ovarian hormone concentrations (Sturdee \& Reece 1979, Rebar \& Spitzer 1987, Kronenberg 1994, Freedman 2001). Valentini et al. (1996) reported that plasma CGRP levels in postmenopausal women are lower than in fertile women. Thus, the up-regulation of CGRP receptors may be involved in the mechanism underlying menopausal hot flashes.

\section{References}

Chen JT, Hirai Y, Seimiya Y, Hasumi K \& Shiraki M 1993 Menopausal flushes and calcitonin-gene-related peptide. Lancet 34249.

Dennis T, Fournier A, Cadieux A, Pomerleau F, Jolicoeur FB, St Pierre S \& Quirion R 1990 hCGRP $_{8-37}$, a calcitonin gene-related peptide antagonist revealing calcitonin gene-related peptide receptor heterogeneity in brain and periphery. Journal of Pharmacology and Experimental Therapeutics 254 123-128.

Freedman RR 2001 Physiology of hot flashes. American Journal of Human Biology 13 453-464.

Fujimori A, Saito A, Kimura S, Watanabe T, Uchiyama Y, Kawasaki H \& Goto K 1989 Neurogenic vasodilation and release of calcitonin gene-related peptide (CGRP) from perivascular nerves in the mesenteric artery. Biochemical and Biophysical Research Communications $1651391-1398$

Fujimori A, Saito A, Kimura S \& Goto K 1990 Release of calcitonin gene-related peptide (CGRP) from capsaicin-sensitive vasodilator nerves in the rat mesenteric artery. Neuroscience Letters $\mathbf{1 1 2}$ 173-178.

Gangula PRR, Lanlua P, Wimalawansa S, Supowit S, DiPette D \& Yallampalli C 2000a Regulation of calcitonin gene-related peptide expression in dorsal root ganglia of rats by female sex steroid hormones. Biology of Reproduction 62 1033-1039.

Gangula PRR, Wimalawansa SJ \& Yallampalli C $2000 b$ Pregnancy and sex steroid hormones enhance circulating calcitonin generelated peptide concentrations in rats. Human Reproduction $\mathbf{1 5}$ 949-953.

Gennari C \& Fischer JA 1985 Cardiovascular action of calcitonin gene-related peptide in humans. Calcified Tissue International 37 581-584.

Han SP, Naes L \& Westfall TC 1990 Inhibition of periarterial nerve stimulation-induced vasodilation of the mesenteric arterial bed by CGRP (8-37) and CGRP receptor desensitization. Biochemical and Biophysical Research Communications 168 786-791.

Holzer P 1992 Peptidergic sensory neurons in the control of vascular function: mechanism and significance in the cutaneous and splanchnic vascular beds. Reviews of Physiology, Biochemistry and Pharmacology 121 49-146.

Ishida-Yamamoto A \& Tohyama M 1989 Calcitonin gene-related peptide in the nervous tissue. Progress in Neurobiology 33 335-386.

Jager K, Muench R, Seifert H, Beglinger C, Bollinger A \& Fisher JA 1990 Calcitonin gene-related peptide (CGRP) causes redistribution of blood flow in humans. European Journal of Clinical Pharmacology 39 491-494.

Jernbeck J, Edner M, Dalsgaard CJ \& Pernow B 1990 The effect of calcitonin gene-related peptide (CGRP) on human forearm blood flow. Clinical Physiology 10 335-343.

Juaneda C, Dumont Y \& Quirion R 2000 The molecular pharmacology of CGRP and related peptide receptor subtypes. Trends in Pharmacological Sciences 21 432-438.

Kawasaki H, Takasaki K, Saito A \& Goto K 1988 Calcitonin gene-related peptide acts as a novel vasodilator neurotransmitter in mesenteric resistance vessels of the rat. Nature 335 164-167.

Kobayashi T, Ushijima O, Chen JT, Shiraki M, Ohta T \& Kiyoki M 1995 Basal tail skin temperature elevation and augmented response to calcitonin gene-related peptide in ovariectomized rats. Journal of Endocrinology 146 431-437.

Kronenberg F 1994 Hot flashes: phenomenology, quality of life, and search for treatment options. Experimental Gerontology 29 319-336.

Lee Y, Takami K, Kawai Y, Girgis S, Hillyard CJ, MacIntyre I, Emson PC \& Tohyama M 1985 Distribution of calcitonin gene-related peptide in the rat peripheral nervous system with reference to its coexistence with substance P. Neuroscience 15 $1227-1237$

Lei S, Mulvany MJ \& Nyborg NC 1994 Characterization of the CGRP receptor and mechanisms of action in rat mesenteric small arteries. Pharmacology and Toxicology 74 130-135.

Lowry OH, Rosebrough NJ, Farr AL \& Randall RJ 1951 Protein measurement with the Folin phenol reagent. Journal of Biological Chemistry 193 265-275.

Marshall I, Al-Kazwini SJ, Roberts PM, Shepperson NB, Adams M \& Craig RK 1986 Cardiovascular effects of human and rats CGRP compared in the rat and other species. European Journal of Pharmacology 123 207-216.

McEwan JR, Benjamin N, Larkin S, Fuller RW, Dollery CT \& MacIntyre I 1988 Vasodilatation by calcitonin gene-related peptide and by substance P: a comparison of their effects on resistance and capacitance vessels of human forearms. Circulation 77 1072-1080.

Mimeault M, Fournier A, Dumont Y, St Pierre S \& Quirion R 1991 Comparative affinities and antagonistic potencies of various human calcitonin gene-related peptide fragments on calcitonin gene-related peptide receptors in brain and periphery. Journal of Pharmacology and Experimental Therapeutics 258 1084-1090.

Rand RP, Burton AC \& Ing T 1965 The tail of the rat in temperature regulation and acclimatization. Canadian Journal of Physiology and Pharmacology 123 207-216.

Rebar R \& Spitzer L 1987 The physiology and measurements of hot flushes. American Journal of Obstetrics and Gynecology 156 1284-1288

Rosenfeld MG, Mermod JJ, Amara SG, Swanson LW, Sawchenko PE, Rivier J, Vale WW \& Evans RM 1983 Production of a novel neuropeptide encoded by the calcitonin gene via tissue-specific RNA processing. Nature 304 129-135.

Saggese G, Bertelloni S, Baroncelli GI, Pelletti A \& Benedetti U 1990 Evaluation of a peptide family encoded by the calcitonin gene in selected healthy pregnant women: a longitudinal study. Hormone Research 34 240-244.

Shen YT, Pittman TJ, Buie PS, Bolduc DL, Kane SA, Koblan KS, Gould RJ \& Lynch JJ 2001 Functional role of alpha-calcitonin gene-related peptide in the regulation of the cardiovascular system. Journal of Pharmacology and Experimental Therapeutics 298 551-558.

Stevenson JC, Macdonald DW, Warren RC, Booker MW \& Whitehead MI 1986 Increased concentration of circulating calcitonin gene related peptide during normal human pregnancy. British Medical Journal 293 1329-1330.

Sturdee DW \& Reece BL 1979 Thermography of menopausal hot flashes. Maturitas 1 201-205.

Uddman R, Edvinsson L, Ekblad E, Hakanson R \& Sundler F 1986 Calcitonin gene-related peptide (CGRP): perivascular distribution and vasodilatory effect. Regulatory Peptides 15 1-23. 
Valentini A, Petraglia F, De Vita D, Nappi C, Margutti A, Degli Uberti EC \& Genazzani AR 1996 Changes of plasma calcitonin gene-related peptide levels in post menopausal women. American Journal of Obstetrics and Gynecology 175 638-642.

Wanaka A, Matsuyama T, Yoneda S, Kamada T, Emson PC, Hillard J, Girgis SJ, MacIntyre I \& Tohyama M 1987 Distribution patterns of calcitonin gene-related peptide-containing fibers in the wall of the three different arteries: an immunohistochemical study. Cellular Molecular Biology 33 201-209.

Wei JW, Janis RA \& Daniel EE 1976 Isolation and characterization of plasma membrane from rat mesenteric arteries. Blood Vessels $\mathbf{1 3}$ 279-292.

Wimalawansa SJ, Emson PC \& MacIntyre I 1987 Regional distribution of calcitonin gene-related peptide and its specific binding sites in rats with particular reference to the nervous system. Neuroendocrinology 46 131-136.

Wu D, Eberlein W, Rudolf K, Engel W, Hallermayer G \& Doods H 2000 Characterisation of calcitonin gene-related peptide receptors in rat atrium and vas deferens: evidence for a $[\mathrm{Cys}(\mathrm{Et})(2,7)] \mathrm{hCGRP}-$ preferring receptor. European Journal of Pharmacology 400313 319.

Zaidi M, Bevis PJR, Lynch C, Stevenson JC \& MacIntyre I 1985 Circulating CGRP comes from the perivascular nerves. European Journal of Pharmacology 117 283-284.

Received in final form 5 June 2002 Accepted 12 June 2002 